\title{
Doubts about concessions
}

Polish universities seen at last to have won concessions from the government in their campaign against the proposed reform of the 1982 Higher Education Act. According to the leading Warsaw weekly, Polityka, the government Committee for Social and Political Affairs, in charge of drafting the reform, has given way on five major points. But many academics fear that these concessions are essentially cosmetic, designed to allay further, lastminute criticism of the amendments which, it is believed, will go before the Sejm (Parliament) in the near future.

According to Polityka, the Committee for Social and Political Affairs has decided:

Oto drop proposals to replace tenure for senior lecturers and professors and to replace it by a contract system;

to drop the proposal that rectors, prorectors and deans should be appointed by the Minister of Higher Education and Science instead of being elected by the universities themselves;

to retain elections to the Main Council for Higher Education, the 70-person body representing all Polish universities and higher education schools (except the private Catholic University of Lublin);

to allow universities to decide their own statutes instead of having to conform to a standard form of statutes dictated by the Minister;

Oto retain some form of student "selfgovernment committees", instead of replacing them by bodies linked to party youth organizations.

Although, formally, there was a major public debate on the proposed changes earlier this year, the Polityka article is the first open admission that the universities (as represented by the Main Council) are diametrically opposed to the government over the changes.

Moreover, Polityka cited several leading academics who contradict the assertion of the Minister of Science and Higher Education, Dr Benson Miskiewicz, that falling academic performance over the past three years is clear proof that the 1982 act has been used to "destabilize" the universities. The rectors of Warsaw Polytechnic University and the Jagellonian University of Kraków, in particular, are quoted as saying that while, unfortunately, there has been a decline both in the percentage of students completing their courses and in the quality of their final dissertations, there is considerable doubt as to whether this is a result of the 1982 act. This apparent "openness" of the Polityka article has given some encouragement to the more optimistic academics.

On the other hand, the less optimistic point out, there was never any real likelihood that tenure would be abolished.
Even a tenured lecturer can be dismissed by special decision of the Council of State (as happened recently in the case of Dr Lessek Nowak, a social scientist at the University of Poznan) and the proposal was probably included in the draft as a bargaining counter. The election of university officials will be carried out by a senate which will consist almost entirely of senior tenured staff, and without the participation of representatives of the student body and non-teaching academic employees. The abolition of elections to the Main Council is said to have been proposed, as a result of the vehement opposition shown by that body to the changes, as a means of reducing its power. Although it will not be changed into a puppet body of ministerial appointees, the Main Council still loses its decision-making powers, so that, under the reform, the minister will have only to "consult" the Main Council on terms of academic employment.
Even more serious, the minister will still retain what many see as the greatest threat of the reform, the right to dismiss or suspend any university official or lecturer, expel or suspend any student, and close down or suspend any department, without appeal or independent disciplinary hearing, if he deems it "in the public interest".

Furthermore, one should read not only Polityka, which still enjoys "by inertia" something of its pre-1981 reputation for a liberal outlook (by Polish standards) but also the Party daily Trybuna Ludu, which, only a few days previously, had given its own views of the reform. According to Trybuna Ludu, opposition to the reform is virtually equivalent to opposition to the Party, and, it implied, under the amended act, university employment would be dependent on an oath of loyalty to the concept of a socialist university. The idea of such an "oath" came as a surprise to most academics, who throughout the whole campaign have been largely dependent on "leaks" to the Solidarity underground press for information about what the government was planning. Vera Rich

\section{British geology}

\section{Crying in the wilderness}

THE saga of the declining budget for British geology took a new turn last week. In the most public and formal cri de coeur from the geological community so far, nine presidents and chairmen of major professional bodies* published a tract in which they summarize the present economic circumstances of their disciplines and the dire consequences they anticipate if fundamental changes, including an increased proportion of mineral taxes to be

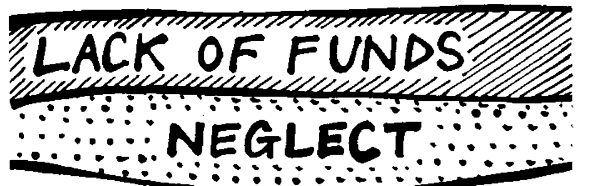

\section{BRITISH GEOLOGY}

\section{B.}

spent on research, are not soon made.

The decline in research commissioned by government departments, as well as cuts in funds from the Natural Environment Research Council (NERC) has led to a virtual halt in strategic surveying by the British Geological Survey (BGS) (see Nature 311, 499;1984). The new document, sent to Secretary of State for Education and Science Sir Keith Joseph last week, summarizes this position but puts it in the most general economic terms. In 1983, the total mineral production (including oil) by Britain was worth $£ 24,000$ million; the tax and royalty payments from North Sea oil alone in 1984 amounted to $£ 9,000$ million. Funds from NERC for the geological sciences in 1983-
84 amounted to 0.0043 per cent of the latter figure.

The signatories of the tract go on to outline the "impasse" with which they are confronted. In answer to the question of whether academic and institutional research is worth saving, they say, "the common government reponse is that if industry wants it, industry will pay for it. Industry usually replies that, as they have already paid for it in taxes and royalties, government should pay." The government's way out, say the signatories, is to tell the universities to fund research from consultancy service, an approach which, while being increasingly adopted, is bringing universities into conflict with the private sector.

The solution proposed is, in the short term, an injection of $£ 15$ million "earmarked specifically for the geological sciences... adequately to fund systematic surveys, to computerize national databanks, to re-equip research centres of excellence and to allow UK participation in major international projects". And NERC? The document uses weasel words: "The role of NERC needs to be evaluated and the rationality of its Corporate Plan assessed". Philip Campbell

* Signatories: P.Allen (chairman. British National Committee for Geology), C.H.Holland (president, Geological Society), D.C.Ion (president, Institution of Geologists). W.G. Yuill (president, Institution of Mining and Mineralogy), J.Birks (president, Institute of Petroleum). P.I.Allsop (president. Institution of Mining Engineers), M.G.Audley-Charles (chairman, Committee of Heads of University Geology Departments), R.F.P.Hardman (chairman. Petroleum Exploration Society of Great Briatain) and J.R.Vail (chairman. Committee of Heads of Polytechnic Geology Departments) 